\title{
Mancha Foliar em Antúrio Causada por Sclerotium rolfsii
}

\author{
Cleber Novais Bastos \\ Comissão Executiva do Plano da Lavoura Cacaueira, Estação de Recursos Genéticos José Haroldo, Cx. Postal 46, \\ CEP 67105-970, Marituba, PA, Brasil, e-mail:cleber@ufpa.br
}

Autor para correspondência: Cleber N. Bastos

\begin{abstract}
Sclerotium rolfsii leaf spot on Anthurium plowmanii Anthurium plowmanii is reported for the first time as a host of Sclerotium rolfsii in the State of Pará, Brazil.
\end{abstract}

\begin{abstract}
O gênero Anthurium Schott (Araceae) compreende mais de 600 espécies, normalmente herbáceas, epífitas, nativas da América tropical, conhecidas popularmente por Antúrio (Tombolato, A.F.C. Cultivo comercial de plantas ornamentais. Campinas SP. IAC. 2004). Em junho de 2006 foram observadas lesões em folhas de Anthurium plowmanii Croat na Estação de Recursos Genéticos "José Haroldo", município de Marituba PA. Os sintomas caracterizavam-se por manchas de coloração pardo-escura, sem bordos definidos, necróticas, de tamanho variável. Na face inferior da folha, verificava-se crescimento micelial branco e presença de numerosos escleródios pequenos, arredondados, de cor branca no início e depois progredindo para pardo-escura. Em estádio mais avançado da infecção, ocorriam rasgaduras das folhas. $\mathrm{O}$ isolamento do agente etiológico foi efetuado a partir de fragmentos do tecido

ferimentos ou previamente feridas com auxílio de estilete esterilizado, e submetidas à câmara úmida. Como controle foram usados discos de BDA. Após três ou quatro dias, foi observado o início do desenvolvimento das lesões nas folhas inoculadas com e sem ferimento. Posteriormente, as lesões atingiram tamanho variado (Figura 1B), sendo o patógeno reisolado dos tecidos infectados e comparado ao isolado original, completando-se assim os postulados de Koch. O patógeno foi identificado como $S$. rolfsii com base nas características morfológicas das colônias de culturas e dos escleródios. Não foram encontrados registros anteriores sobre a ocorrência de $S$. rolfsii causando mancha foliar em $A$. plowmanii, embora no Brasil o patógeno já tenha sido verificado causando murcha e podridão de raízes em Anthurium spp. (Mendes et al., Fungos em Plantas no Brasil. Brasília DF. EMBRAPA. 1998).
\end{abstract} foliar de amostras com sintomas da doença e pelo processo direto de isolamento, retirando-se escleródios com estilete esterilizado e transferindo-os para tubos de ensaio com BDA, que foram incubados a $25 \pm 1{ }^{\circ} \mathrm{C}$, em ausência de luz. Os isolamentos produziram culturas puras que caracterizaram pelo desenvolvimento de um micélio de coloração branca. $\mathrm{O}$ crescimento do fungo em placas de Petri contendo BDA resultou em uma massa micelial algodonosa de coloração branca e formação de numerosos escleródios arredondados de 0,5 - 1,5 mm de diâmetro, de coloração branca no início e, posteriormente, pardo-escura, típicos de Sclerotium rolfsii Sacc. (Figura 1A). Os testes de patogenicidade foram realizados em plantas de $A$. plowmanii mantidas em casa-devegetação. A inoculação consistiu na deposição de discos de micélio de $5 \mathrm{~mm}$ de diâmetro na superfície de folhas, sem
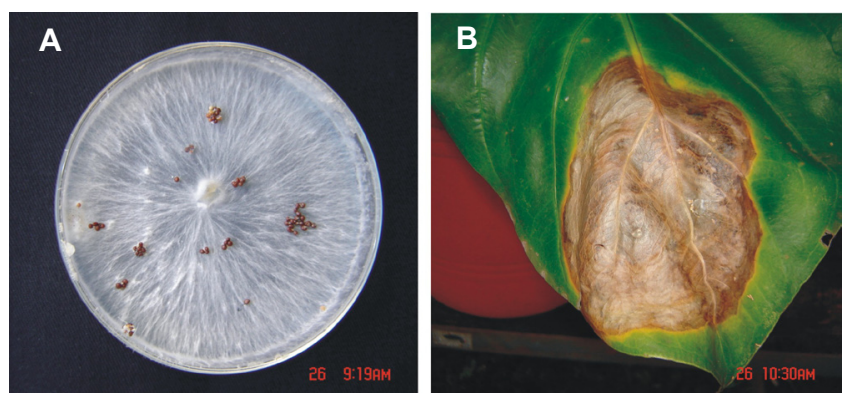

FIG. 1 -A. Colônia de Sclerotium rolfsii em BDA, com escleródios; B. Sintomas do patógeno em folha de Anthurium plowmanii, 6 dias após inoculação artificial.

Recebido 12 Fevereiro 2007 - Aceito 17 Maio 2007 - FB 7013 